(c) American Dairy Science Association, 2004.

\title{
Bovine Somatotropin and Rumen-Undegradable Protein Effects in Prepubertal Dairy Heifers: Effects on Body Composition and Organ and Tissue Weights*
}

\author{
U. Moallem, ${ }^{1}$ G. E. Dahl, ${ }^{1}$ E. K. Duffey, ${ }^{1}$ A. V. Capuco, ${ }^{2}$ D. L. Wood, ${ }^{2}$ \\ K. R. McLeod, ${ }^{2}$ R. L. Baldwin, $\mathrm{VI}^{2}{ }^{2}$ and R. A. Erdman ${ }^{1}$ \\ ${ }^{1}$ Department of Animal and Avian Sciences, University of Maryland, College Park 20742 \\ ${ }^{2}$ Bovine Functional Genomics Laboratory Animal and Natural Resources Institute \\ Agricultural Research Service, USDA Beltsville, MD 20705
}

\begin{abstract}
The objectives of this study were to determine the effect of recombinant bovine somatotropin (bST) and added dietary rumen undegradable protein (RUP) on organ and tissue weights and body composition in growing dairy heifers. Thirty-two Holstein heifers were in the experiment, 8 killed initially at 3 mo of age, with the remaining 24 Holstein heifers randomly assigned to treatments $(\mathrm{n}=6)$ consisting of $0.1 \mathrm{mg} / \mathrm{kg}$ of body weight per day of bST and $2 \%$ added dietary RUP (dry matter basis) applied in a $2 \times 2$ factorial design. A total of 6 heifers per treatment group ( 3 each at 5 and 10 mo of age), were slaughtered to determine body composition and organ masses. Feed intake measured from group intakes were increased by 0.25 and $0.35 \mathrm{~kg} / \mathrm{d}$ with bST and RUP, respectively. Administration of bST tended to increase the weights of visceral organs including heart, kidney, and spleen by 16,16 , and $38 \%$, respectively. At 10 mo of age, there was a trend for increased empty body weights (EBW) and non-carcass components for heifers treated with bST, but there were no effects of RUP. Body components and organ weights, expressed as a percentage of BW were not affected by RUP or bST. Somatotropin increased ash weight at 10 mo without affecting amounts of protein, fat, and energy. Rates of ash deposition between 3 and 10 mo of age were increased 7 and $4 \mathrm{~g} / \mathrm{d}$ by bST and RUP, respectively. There were no treatment effects on rates of body fat, protein, and energy deposition. Bovine somatotropin and RUP altered the metabolism of growing heifers in a manner that was consistent with increased rates of skeletal growth. This suggests that nutritional and endocrine manipulations could increase growth
\end{abstract}

Received November 21, 2003.

Accepted January 21, 2004.

Corresponding author: R. A. Erdman; e-mail: erdman@umd.edu.

"This research was supported by Research Grant Award No. US2921-97R from BARD, The United States-Israel Binational Agricultural Research and Development Fund. rates of skeletal tissues without increasing fat deposition in prepubertal dairy heifers.

(Key words: dairy heifer, skeletal growth, body composition, somatotropin)

Abbreviation key: EBW = empty body weight, $\mathbf{G I}=$ gastrointestinal, $\mathbf{L B W}=$ live body weight, $\mathbf{N C}=$ noncarcass fraction.

\section{INTRODUCTION}

Increasing growth rates of dairy replacement heifers reduces the interval from birth to first calving, which has the potential to increase the profitability of dairy herds (Heinrichs, 1993). In addition, it is well established that there is a positive relationship between BW at calving and milk production in first-lactation dairy cows (Clark and Touchberry, 1962; Hardville and Henderson, 1966; Hoffman, 1997). Keown and Everett (1986) observed maximal first-lactation milk yield in Holstein replacement heifers weighing between 590 and $635 \mathrm{~kg}$ at calving. Furthermore, adequate skeleton size is needed to minimize dystocia during the first parturition (Markusfeld and Ezra, 1993). Analysis of first-lactation production in commercial herds in Israel (Markusfeld and Ezra, 1993) showed that body skeleton size (withers height) at calving was positively related, whereas BW was negatively related to first-lactation FCM yield, suggesting that skeletal size rather than BW was the most important factor affecting first-lactation milk yield. These results were similar to those of Sieber et al. (1988), where again withers height was a more important factor than BW in relation to firstlactation milk yield.

The majority of skeletal growth occurs during the prepubertal period (Heinrichs and Hargrove, 1987), when rates of withers and hip height growth are as much as 3-fold greater than after puberty (Barash et al., 1994a, 1994b). Relative rates of skeletal growth as measured by changes in withers or hip height decrease gradually over time from as much as $5 \mathrm{~cm} / \mathrm{mo}$ at $2 \mathrm{mo}$ 
of age to around $1 \mathrm{~cm} / \mathrm{mo}$ during the postpubertal period (Heinrichs and Hargrove, 1987). This suggests that the greatest opportunity for enhancing skeletal growth is during the prepubertal period. Increases in rates of skeletal and BW growth in prepubertal dairy heifers can be achieved by increasing the energy density of diets. However, increasing rates of BW gain above $1 \mathrm{~kg} /$ $\mathrm{d}$ reduces mammary parenchymal tissue and increases mammary fat deposition (Sejrsen et al., 1982; Capuco et al., 1995), and both factors are associated with lower milk production during the first lactation. Thus, methods to increase skeletal growth rates without increasing fat deposition might be used to accelerate growth without increasing fattening, thereby preventing detrimental effects of accelerated growth on mammary development.

Somatotropin, particularly when used in the presence of increased intestinal protein such as abomasal infusion of casein (Houseknecht et al., 1992; Bruckental et al., 1996) has been shown to enhance $\mathrm{N}$ retention by Holstein steers, suggesting that lean tissue and possibly skeletal deposition may be enhanced by the addition of bST and dietary RUP. Previous studies with bST showed positive effects on development of mammary secretory tissue between birth and conception (Tucker, 1987; Sejrsen, 1994). Radcliff et al. (1997) and Grings et al. (1990) reported increased withers height at puberty with prepubertal bST treatment. Collectively, these experiments suggest that bST in combination with added RUP might provide a practical means to optimize skeletal growth rates during the prepubertal period without having negative impact on mammary development. The objectives of this study were to determine the effects of administration of bST and dietary RUP on body composition, and organ and tissue growth rates in prepubertal dairy heifers.

\section{MATERIALS AND METHODS}

\section{Animal Management and Feeding}

The experimental protocol was approved by the University of Maryland Institutional Animal Care and Use Committee and was conducted at Central Maryland Research and Education Center Dairy Unit located in Clarksville, Maryland. Thirty-two Holstein heifer calves, 16 each from 2 separate groups (replicates) of purchased calves, were a subset of a larger growth experiment to evaluate the impact of prepubertal bST and RUP on subsequent milk production. Calves were raised in either individual calf hutches or pens until weaning at $60 \mathrm{~d}$ of age. Calves were raised on $4.5 \mathrm{~L} / \mathrm{d}$ of a commercial milk replacer and ad libitum water and starter mix until weaning at $60 \mathrm{~d}$ of age. After weaning, heifers were fed starter mix and water ad libitum until
Table 1. Ingredient and chemical composition of control and RUP diets.

\begin{tabular}{lrr}
\hline & Control & Added RUP \\
\cline { 2 - 3 } & & \% of DM \\
\cline { 2 - 3 } Ingredients & & \\
Corn grain, ground & 2.3 & $\ldots$ \\
Soybean meal & 3.7 & 0.7 \\
Excel soy & 11.3 & 12.8 \\
White fish meal & $\ldots 4.4$ & 4.7 \\
Corn silage & 64.4 & 64.4 \\
Timothy hay & 16.7 & 16.7 \\
NaCl & 0.4 & 0.2 \\
Mineral and vitamins mix $^{2}$ & 1.4 & 0.4 \\
Chemical composition & & \\
DM & 46.2 & 46.3 \\
CP & 14.9 & 16.9 \\
RUP & 5.9 & 7.9 \\
ADF & 24.1 & 24.2 \\
NDF & 3.8 & 3.8 \\
Ca & 0.7 & 0.7 \\
P & 0.5 & 0.5 \\
\hline
\end{tabular}

${ }^{1}$ Excel soy, Excel Soybean Technologies, Oskaloosa, KS.

${ }^{2}$ Formulated to provide (per kg of DM) 2551 IU of vitamin A, 426 IU of vitamin D, 8.5 IU of vitamin E, $0.06 \mathrm{~g}$ of P, $0.17 \mathrm{~g}$ of Ca, 19.2 $\mathrm{mg}$ of $\mathrm{Fe}, 15.4 \mathrm{mg}$ of $\mathrm{Zn}, 15.4 \mathrm{mg}$ of $\mathrm{Mn}, 7.7 \mathrm{mg}$ of $\mathrm{Cu}$, and $0.3 \mathrm{mg}$ of Se.

$90 \mathrm{~d}$ of age and transitioned onto the TMR that was fed from 3 mo until slaughter. All calves selected for the study were in good health and averaged $90 \mathrm{~kg} \mathrm{BW}$ at the start of the experiment. Thirty-two Holstein heifers were in the experiment, 8 killed initially at 3 mo of age, with the remaining 24 Holstein heifers randomly allotted to one of 4 treatment groups and group fed by treatment until slaughter. Treatments consisted of recombinant bST, with or without $2 \%$ added dietary RUP, applied in a $2 \times 2$ factorial design. The control diet was formulated according to $1989 \mathrm{NRC}$ requirements to meet nutrient requirements including energy and protein needs for a 200-kg large-breed heifer with a liveweight growth rate of $800 \mathrm{~g} / \mathrm{d}$. A complete description of the chemical and ingredient content of experimental diets, housing, and feeding methods is provided in a companion manuscript detailing the growth experiment (Moallem et al., 2004). The experimental diets, fed as TMR (Table 1), were formulated to be equal in energy and RDP content but differed only in RUP content. The added RUP diets contained $16.9 \% \mathrm{CP}$ with 9.0\% RDP and 7.9\% RUP (DM basis) compared with 14.9\% CP with 9.0\% RDP and 5.9\% RUP in the control diet. Sustained release recombinant bST (Posilac, Monsanto Co., St. Louis), equivalent to $0.1 \mathrm{mg} / \mathrm{kg}$ BW per day, was injected subcutaneously (scapular region) every $14 \mathrm{~d}$ in bST-treated heifers.

\section{Slaughter and Sampling Procedures}

At 3 mo of age and prior to initiation of treatment, 8 heifers were killed to determine pretreatment body 
composition for estimating rates of body component deposition. Twenty-four heifers, 6 per treatment group (3 each at 5 and 10 mo of age), were slaughtered to determine effects of treatment on body composition. These ages were selected to represent the midpoint of prepuberty $(5 \mathrm{mo})$ and the estimated age of puberty $(10 \mathrm{mo})$. Animals were transported to the USDA abattoir (Beltsville Agriculture Research Center, Maryland), where they were stunned using a captive bolt gun followed by exsanguination. Empty body tissues were separated into carcass and non-carcass (NC) fractions. The NC fraction consisted of the head, feet and tail, blood, hide, internal organs, empty intestinal tract segments, and mammary gland. Blood was collected, weighed, and then pooled with the NC fraction. Internal organs including heart, lungs, liver, kidney, and spleen were weighed separately prior to pooling with the NC fraction. Gastrointestinal (GI) segments with digesta contents were isolated (rumen and reticulum, omasum, abomasum, small intestine and large intestine, and cecum) by ligation, separated, and weighed. Subsequently, GI tissue segments were emptied, washed with cool water, drained, weighed empty, and pooled with the NC fraction. Gut fill within intestinal tract was determined as the difference between full and empty weights of GI tract segments. The mammary gland was removed and weighed, and the hide surrounding the gland was separated and weighed. The mammary gland was split down the medial line and half of the gland was weighed and retained as a separate fraction for histochemical analysis presented in another report, while the remainder was analyzed separately and data combined with the NC fraction. The carcass was split down the middle, and each half was weighed to the nearest $0.05 \mathrm{~kg}$, shrouded, chilled to $4^{\circ} \mathrm{C}$ for 2 to $3 \mathrm{~d}$ and then reweighed prior to grinding left half only. Any loss of weight during chilling was considered to be water. Non-carcass fractions were ground 4 times on the day of slaughter in a 20-cm Autio grinder (Autio Company, Astoria, OR) using a plate with holes of 13 $\mathrm{mm}$ diameter. The carcass was ground in a similar manner 2 to $3 \mathrm{~d}$ after slaughter. Two samples (950 to $1000 \mathrm{~g})$ were taken from the last grinding. Samples were stored frozen and DM was determined by freezedrying. The dried samples from each fraction were pooled and ground with dry ice in a Wiley mill through a 2-mm screen, and an aliquot was stored frozen for subsequent chemical analyses.

\section{Chemical Analysis}

Chemical analyses were conducted in triplicate on ground freeze-dried carcass and NC fractions. Total N was determined by combustion analysis (Leco $\mathrm{C} / \mathrm{N}$
2000; model 601-900-000, Leco Corporation, St. Joseph, $\mathrm{MI})$, and $\mathrm{CP}$ was calculated as $\mathrm{N} \times 6.25$. Ether extract was determined by AOAC (1984) procedures modified to use a sample of 5 to $7 \mathrm{~g}$. Ash content was measured by combustion at $600^{\circ} \mathrm{C}$ for $16 \mathrm{~h}$. Energy content of the tissues was determined by adiabatic oxygen bomb calorimetry (model 1271, Parr Instruments, Moline, IL). Empty body composition of individual animals was the weighted average of carcass and NC fractions. Feed samples were collected weekly, pooled by dietary treatment, subsampled, and submitted for chemical analysis for DM, NDF, ADF, Ca, P, and K at a commercial feed analysis laboratory (Cumberland Valley Laboratories, Hagerstown, MD).

\section{Statistical Analysis}

Chemical analysis and BW of the 8 heifers killed at $90 \mathrm{~d}$ were used to develop regression equations based on BW to predict initial amounts of body chemical components at $90 \mathrm{~d}$ of age and prior to treatment initiation for animals killed at 5 and 10 mo. Body weight was used directly as a covariant in the analysis of covariance using the Mixed Procedure of SAS (SAS 8.0) for a heifers killed at 5 and 10 mo of age in the analysis of body composition and tissue and organ weights. The statistical model included effects of covariate, bST, RUP, and $\mathrm{RUP} \times \mathrm{bST}$ effects. Replicate within treatment was used as the random term for treatment effects with error degrees of freedom approximated using the KenwardRoger option within the mixed procedure. For data representing daily deposition of body components from 90 $\mathrm{d}$ to 10 mo of age shown in Table 8 below, total deposition of chemical components represented the difference between estimated components at $90 \mathrm{~d}$ based on BW and measured components at $10 \mathrm{mo}$ of age. The statistical analysis model for these data was identical to that previously described, except that BW was not used as a covariate, since it had already been used to predict initial body chemical components. We used probability values of $(P<0.05)$ to define statistically significant results with statistical trends being defined at $(P<$ $0.10)$. All body tissue and organ weights and chemical composition data for individual treatments are reported as least square means.

\section{RESULTS}

\section{Body Tissue and Organ Weights}

The previously reported daily DMI between 3 and 10 mo of age were 4.8, 5.2, 5.3, and $5.4 \mathrm{~kg}$ (pooled SED = 0.4 ) for control, bST, RUP, and the combination of RUP and bST (bSTRUP) treatments, respectively (Moallem et al., 2004). Dry matter intake was increased $(P<0.01)$ 
Table 2. Body component weights $(\mathrm{kg})$ of Holstein heifers slaughtered at 5 mo of age fed the control diet, injected with bST, fed a diet with $2 \%$ added RUP, or injected with bST and fed added RUP (bSTRUP).

\begin{tabular}{|c|c|c|c|c|c|c|c|c|}
\hline & \multicolumn{4}{|c|}{ Treatments } & \multirow[b]{2}{*}{ SEM } & \multicolumn{3}{|c|}{ Treatment effects $(P<)$} \\
\hline & Control & bST & RUP & bSTRUP & & $\mathrm{bST}$ & RUP & RUP*bST \\
\hline Heifers, $n$ & 3 & 3 & 3 & 3 & & & & \\
\hline LBW & 103.8 & 123.8 & 126.3 & 118.4 & 14.6 & 0.70 & 0.60 & 0.40 \\
\hline Digesta & 15.8 & 18.1 & 21.3 & 19.6 & 2.5 & 0.95 & 0.19 & 0.39 \\
\hline Empty body & 79.4 & 94.4 & 95.1 & 90.8 & 13.8 & 0.72 & 0.69 & 0.52 \\
\hline Carcass & 44.4 & 56.1 & 55.9 & 52.8 & 8.4 & 0.64 & 0.66 & 0.43 \\
\hline Total non-carcass & 31.5 & 34.3 & 34.2 & 33.9 & 4.7 & 0.81 & 0.82 & 0.77 \\
\hline \multicolumn{9}{|l|}{ Empty digestive organs } \\
\hline Rumen and reticulum & 2.35 & 2.71 & 3.12 & 2.99 & 0.45 & 0.81 & 0.33 & 0.62 \\
\hline Omasum & 0.82 & 1.04 & 0.98 & 1.30 & 0.23 & 0.32 & 0.42 & 0.84 \\
\hline Abomasum & 0.52 & 0.61 & 0.61 & 0.68 & 0.07 & 0.38 & 0.36 & 0.90 \\
\hline Small intestine & 2.90 & 3.35 & 3.06 & 3.51 & 0.47 & 0.37 & 0.76 & 0.99 \\
\hline Large intestine & 1.92 & 1.80 & 2.33 & 1.75 & 0.37 & 0.39 & 0.66 & 0.57 \\
\hline Total digestive tract & 8.46 & 9.45 & 10.08 & 10.26 & 1.55 & 0.72 & 0.49 & 0.81 \\
\hline \multicolumn{9}{|l|}{ Visceral organs } \\
\hline Liver & 1.69 & 2.22 & 2.11 & 2.38 & 0.39 & 0.37 & 0.51 & 0.75 \\
\hline Lungs & 1.07 & 1.23 & 1.22 & 1.10 & 0.14 & 0.92 & 0.95 & 0.37 \\
\hline Heart & 0.57 & 0.57 & 0.64 & 0.64 & 0.06 & 0.96 & 0.27 & 0.92 \\
\hline Kidney & 0.45 & 0.53 & 0.47 & 0.55 & 0.09 & 0.43 & 0.82 & 0.98 \\
\hline Spleen & 0.19 & 0.28 & 0.29 & 0.33 & 0.08 & 0.47 & 0.40 & 0.82 \\
\hline Blood & 3.51 & 4.09 & 4.95 & 3.84 & 0.79 & 0.76 & 0.52 & 0.36 \\
\hline
\end{tabular}

by both bST and RUP. Treatment means for body tissue and organ and weights expressed in kilograms in heifers slaughtered at 5 and 10 mo of age shown in Tables 2 and 3, respectively. Most changes in tissue and organ weights were statistically nonsignificant, but followed changes in live body weight (LBW). Although LBW was numerically higher for both bST and RUP treatments at both 5 and 10 mo of age and similar in magnitude to those observed in the companion growth experiment (Moallem et al., 2004), differences were not significant.
There was a trend for increased empty BW $($ EBW $)(P=$ $0.07)$ and increased non-carcass weight $(P=0.09)$ for heifers treated with bST $(P=0.07)$ at 10 mo of age (Table 3).

Consistent with changes in DMI and LBW, weights of many of the digestive organs were numerically higher for bST and RUP treatments at both 5 (Table 2) and 10 mo of age (Table 3). Similar effects were observed for visceral organs, which were numerically greater with bST and RUP addition. At 10 mo of age, kidney

Table 3. Body component weights $(\mathrm{kg})$ of Holstein heifers slaughtered at 10 mo of age fed the control diet, injected with bST, fed a diet with $2 \%$ added RUP, or injected with bST and fed added RUP (bSTRUP).

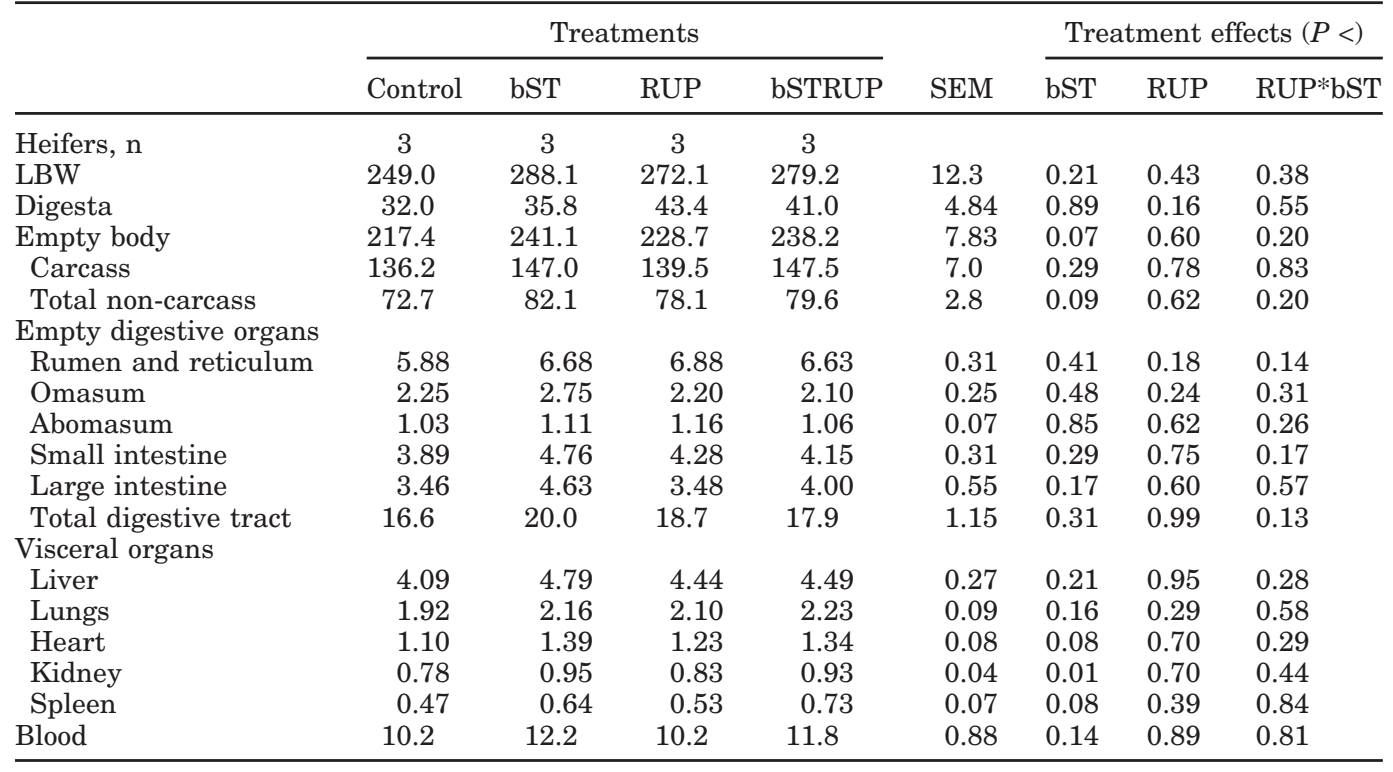


Table 4. Body component weights (\% of empty body weight) by treatment of Holstein heifers slaughtered at 5 mo of age fed the control diet, injected with bST, fed a diet with $2 \%$ added RUP, or injected with bST and fed added RUP (bSTRUP).

\begin{tabular}{|c|c|c|c|c|c|c|c|c|}
\hline & \multicolumn{4}{|c|}{ Treatments } & \multirow[b]{2}{*}{ SEM } & \multicolumn{3}{|c|}{ Treatment effects $(P<)$} \\
\hline & Control & $\mathrm{bST}$ & RUP & bSTRUP & & bST & RUP & $\mathrm{RUP}^{*} \mathrm{bST}$ \\
\hline Heifers, $\mathrm{n}$ & 3 & 3 & 3 & 3 & & & & \\
\hline Digesta, $\%$ of live weight & 17.6 & 17.1 & 19.7 & 18.8 & 0.88 & 0.47 & 0.08 & 0.88 \\
\hline Carcass & 48.1 & 51.6 & 49.7 & 49.5 & 0.75 & 0.10 & 0.74 & 0.08 \\
\hline Total non-carcass & 34.2 & 31.4 & 30.7 & 31.9 & 0.87 & 0.44 & 0.17 & 0.10 \\
\hline \multicolumn{9}{|l|}{ Empty digestive organs } \\
\hline Rumen and reticulum & 2.93 & 2.88 & 3.33 & 3.34 & 0.14 & 0.88 & 0.07 & 0.84 \\
\hline Omasum & 1.03 & 1.10 & 1.03 & 1.40 & 0.12 & 0.15 & 0.29 & 0.27 \\
\hline Abomasum & 0.66 & 0.65 & 0.66 & 0.75 & 0.05 & 0.55 & 0.48 & 0.44 \\
\hline Small intestine & 3.51 & 3.53 & 3.36 & 3.95 & 0.27 & 0.31 & 0.66 & 0.34 \\
\hline Large intestine & 2.47 & 1.97 & 2.40 & 1.97 & 0.26 & 0.17 & 0.90 & 0.90 \\
\hline \multicolumn{9}{|l|}{ Visceral organs } \\
\hline Liver & 2.14 & 2.37 & 2.24 & 2.56 & 0.11 & 0.09 & 0.29 & 0.75 \\
\hline Lungs & 1.43 & 1.34 & 1.31 & 1.20 & 0.19 & 0.64 & 0.54 & 0.97 \\
\hline Heart & 0.73 & 0.61 & 0.70 & 0.71 & 0.06 & 0.46 & 0.69 & 0.35 \\
\hline Kidney & 0.57 & 0.56 & 0.50 & 0.59 & 0.06 & 0.56 & 0.75 & 0.45 \\
\hline Spleen & 0.25 & 0.30 & 0.29 & 0.34 & 0.05 & 0.37 & 0.45 & 0.92 \\
\hline Blood & 4.27 & 4.38 & 5.29 & 4.17 & 0.46 & 0.30 & 0.43 & 0.22 \\
\hline
\end{tabular}

weights were greater $(P<0.01)$, while heart $(P=0.08)$ and spleen $(P=0.08)$ weights tended to be greater with bST treatment.

Body components expressed as a percentage of EBW of heifers killed at 5 and 10 mo of age are presented in Tables 4 and 5. Digesta fill at 5 mo (Table 4), expressed as percentage of LBW, tended to be greater with RUP treatment. Carcass weights, expressed as a percentage of EBW, tended to be greater $(P=0.10)$ in bST-treated heifers at 5 mo but not at 10 mo age. Both carcass $(P=$ $0.08)$ and total non-carcass $(P=0.10)$ weights were reduced with RUP, but the reduction appeared to be less with bST at 5 mo of age. All other tissue and organ weights, expressed as a percentage of EBW, were not different among treatments. Thus, changes in organ growth appeared to be proportional to LBW gain.

\section{Body Composition}

Least square means for concentration and amount of empty body water, ash, protein, fat, and energy are presented in Tables 6 and 7 for heifers slaughtered at 5 and $10 \mathrm{mo}$ of age, respectively. There were no differences observed for concentrations (\% EBW) of water, ash, protein, fat, or energy, at either 5 or 10 mo between treatment groups. At 5 mo of age, amounts of

Table 5. Body component weights (\% of empty BW) by treatment of Holstein heifers slaughtered at 10 mo of age fed the control diet, injected with bST, fed a diet with $2 \%$ added RUP, or injected with bST and fed added RUP (bSTRUP).

\begin{tabular}{|c|c|c|c|c|c|c|c|c|}
\hline & \multicolumn{4}{|c|}{ Treatments } & \multirow[b]{2}{*}{ SEM } & \multicolumn{3}{|c|}{ Treatment effects $(P<)$} \\
\hline & Control & bST & RUP & bSTRUP & & BST & RUP & $\mathrm{RUP} * \mathrm{bST}$ \\
\hline Heifers, $\mathrm{n}$ & 3 & 3 & 3 & 3 & & & & \\
\hline Digesta, $\%$ of live weight & 13.5 & 13.8 & 15.6 & 15.1 & 1.73 & 0.96 & 0.45 & 0.88 \\
\hline Carcass & 56.9 & 55.8 & 54.8 & 55.0 & 2.02 & 0.92 & 0.63 & 0.86 \\
\hline Total non-carcass & 30.1 & 30.6 & 29.6 & 29.8 & 0.86 & 0.72 & 0.51 & 0.89 \\
\hline \multicolumn{9}{|l|}{ Empty digestive organs } \\
\hline Rumen and reticulum & 2.71 & 2.75 & 2.96 & 2.79 & 0.132 & 0.64 & 0.49 & 0.62 \\
\hline Omasum & 1.05 & 1.15 & 1.02 & 0.882 & 0.139 & 0.90 & 0.41 & 0.49 \\
\hline Abomasum & 0.47 & 0.46 & 0.49 & 0.44 & 0.022 & 0.25 & 0.96 & 0.35 \\
\hline Small intestine & 1.82 & 1.98 & 1.83 & 1.75 & 0.112 & 0.77 & 0.45 & 0.35 \\
\hline Large intestine & 1.61 & 1.90 & 1.56 & 1.68 & 0.229 & 0.43 & 0.59 & 0.75 \\
\hline \multicolumn{9}{|l|}{ Visceral organs } \\
\hline Liver & 1.90 & 2.00 & 1.96 & 1.89 & 0.104 & 0.92 & 0.84 & 0.55 \\
\hline Lungs & 0.89 & 0.90 & 0.92 & 0.93 & 0.046 & 0.82 & 0.53 & 0.98 \\
\hline Heart & 0.50 & 0.58 & 0.57 & 0.55 & 0.032 & 0.24 & 0.97 & 0.41 \\
\hline Kidney & 0.36 & 0.39 & 0.36 & 0.39 & 0.018 & 0.12 & 0.97 & 0.90 \\
\hline Spleen & 0.21 & 0.27 & 0.23 & 0.31 & 0.030 & 0.09 & 0.45 & 0.75 \\
\hline Blood & 4.67 & 5.02 & 4.46 & 4.97 & 0.341 & 0.30 & 0.72 & 0.82 \\
\hline
\end{tabular}


Table 6. Chemical body components as percentage of empty BW and total body component weights at 5 mo of age in heifers fed the control diet, injected with bST, fed a diet with $2 \%$ added RUP, or injected with bST and fed added RUP (bSTRUP).

\begin{tabular}{|c|c|c|c|c|c|c|c|c|}
\hline & \multicolumn{4}{|c|}{ Treatments } & \multirow[b]{2}{*}{ SEM } & \multicolumn{3}{|c|}{ Treatment effects $(P<)$} \\
\hline & Control & $\mathrm{bST}$ & RUP & bSTRUP & & $\mathrm{bST}$ & RUP & $\mathrm{RUP}^{*} \mathrm{bST}$ \\
\hline Observations, $\mathrm{n}$ & 3 & 3 & 3 & 3 & & & & \\
\hline Water, \% & 66.5 & 65.1 & 66.0 & 66.9 & 1.34 & 0.84 & 0.65 & 0.41 \\
\hline Ash, \% & 4.8 & 5.4 & 4.9 & 5.3 & 0.37 & 0.27 & 0.94 & 0.78 \\
\hline Crude protein, \% & 18.9 & 19.9 & 19.5 & 19.8 & 0.84 & 0.45 & 0.78 & 0.70 \\
\hline Fat, $\%$ & 9.9 & 9.5 & 9.6 & 8.0 & 0.74 & 0.24 & 0.29 & 0.47 \\
\hline Energy, Mcal/kg & 1.88 & 1.97 & 1.94 & 1.80 & 0.06 & 0.76 & 0.51 & 0.21 \\
\hline \multicolumn{9}{|l|}{ Component } \\
\hline Weight, kg & 79.4 & 94.4 & 95.1 & 90.8 & 13.97 & 0.72 & 0.69 & 0.52 \\
\hline Water, kg & 53.1 & 61.5 & 62.3 & 60.8 & 9.51 & 0.74 & 0.69 & 0.63 \\
\hline $\mathrm{Ash}, \mathrm{kg}$ & 3.8 & 5.1 & 4.5 & 4.7 & 0.55 & 0.23 & 0.83 & 0.38 \\
\hline Crude protein, $\mathrm{kg}$ & 14.7 & 18.9 & 18.5 & 17.8 & 1.79 & 0.53 & 0.69 & 0.39 \\
\hline Fat, kg & 7.8 & 9.0 & 9.7 & 7.4 & 1.73 & 0.76 & 0.95 & 0.36 \\
\hline Energy, Mcal & 149.0 & 186.3 & 189.0 & 163.7 & 27.9 & 0.84 & 0.78 & 0.33 \\
\hline
\end{tabular}

empty body water, ash, protein, and energy were all numerically greater with bST and RUP treatment but differences were not significant. Similar effects were observed in heifers slaughtered at 10 mo of age; however, ash was increased by bST $(\mathrm{P}=0.04)$ and tended to increase with RUP $(P=0.09)$. Although LBW was numerically $23 \mathrm{~kg}$ greater with bST (Table 3 ), the amount of body fat was actually lower, the difference comprising added water and protein. Total energy of the empty body was not altered by RUP or bST.

Growth rate and rate of deposition of individual chemical components for heifers slaughtered at 10 mo of age are presented in Table 8. As previously described, rate of deposition of individual chemical components are based on the difference between actual measured values at 10 mo of age and estimated chemical components at $3 \mathrm{mo}$. The estimated chemical components at
3 mo were based on the relationship between empty body components and BW for heifers slaughtered at 3 mo of age, prior to the start of the experiment. Total LBW and EBW gain were numerically greater for both bST and RUP treatments, but differences were not statistically different. Total gains in empty body ash were increased by 1.5 and $1.2 \mathrm{~kg}$ by bST $(P=0.04)$, and RUP $(P=0.09)$, respectively. Similarly, protein gain was numerically higher with bST and RUP treatment, while fat and energy gains were similar across treatments. Daily rate of ash deposition (Table 8) was increased 7 $\mathrm{g} / \mathrm{d}(P<0.05)$ by bST and tended to increase by $4 \mathrm{~g} / \mathrm{d}$ $(P<0.08)$ by the addition of RUP. Rates of protein deposition were numerically greater with bST and RUP treatments, but differences were not significant. Effects of bST or RUP on rate of fat or energy deposition were not apparent.

Table 7. Chemical body component as percentage of empty BW and total body components weights at 10 mo of age in heifers fed the Control diet, injected with bST, fed a diet with $2 \%$ added RUP, or injected with bST and fed added RUP (bSTRUP).

\begin{tabular}{|c|c|c|c|c|c|c|c|c|}
\hline & \multicolumn{4}{|c|}{ Treatments } & \multirow[b]{2}{*}{ SEM } & \multicolumn{3}{|c|}{ Treatment effects $(P<)$} \\
\hline & Control & bST & RUP & bSTRUP & & bST & RUP & RUP*bST \\
\hline Observations, $\mathrm{n}$ & 3 & 3 & 3 & 3 & & & & \\
\hline Water, \% & 62.1 & 61.1 & 61.2 & 62.3 & 0.98 & 0.98 & 0.92 & 0.44 \\
\hline Ash, \% & 4.9 & 5.1 & 5.1 & 5.6 & 0.30 & 0.33 & 0.33 & 0.69 \\
\hline Crude protein, \% & 18.8 & 19.7 & 19.8 & 20.2 & 0.70 & 0.37 & 0.35 & 0.76 \\
\hline Fat, $\%$ & 14.2 & 14.1 & 13.9 & 11.9 & 0.89 & 0.30 & 0.22 & 0.34 \\
\hline Energy, Mcal/kg & 2.32 & 2.37 & 2.36 & 2.18 & 0.08 & 0.51 & 0.46 & 0.37 \\
\hline \multicolumn{9}{|l|}{ Component } \\
\hline Weight, kg & 216.0 & 239.6 & 230.2 & 236.9 & 8.28 & 0.14 & 0.54 & 0.37 \\
\hline Water, kg & 136.8 & 149.8 & 140.9 & 147.6 & 6.06 & 0.18 & 0.54 & 0.70 \\
\hline Ash, kg & 10.6 & 12.2 & 11.8 & 13.2 & 0.53 & 0.04 & 0.09 & 0.84 \\
\hline $\mathrm{CP}, \mathrm{kg}$ & 41.9 & 47.1 & 45.2 & 47.9 & 2.56 & 0.28 & 0.52 & 0.70 \\
\hline Fat, kg & 31.1 & 34.2 & 32.4 & 28.2 & 2.71 & 0.88 & 0.45 & 0.25 \\
\hline Energy, Mcal & 503 & 570 & 547 & 518 & 29.8 & 0.56 & 0.88 & 0.18 \\
\hline
\end{tabular}


Table 8. Total content of gain and daily gain of BW, empty BW, and chemical body components between 3 and 10 mo of age in heifers fed the control diet, injected with bST, fed a diet with $2 \%$ added RUP, or injected with bST and fed added RUP (bSTRUP).

\begin{tabular}{|c|c|c|c|c|c|c|c|c|}
\hline \multirow[b]{2}{*}{ Item } & \multicolumn{4}{|c|}{ Treatments } & \multirow[b]{2}{*}{ SEM } & \multicolumn{3}{|c|}{ Treatment effects $(P<)$} \\
\hline & Control & bST & RUP & bSTRUP & & bST & RUP & RUP*bST \\
\hline Observations, $\mathrm{n}$ & 3 & 3 & 3 & 3 & & & & \\
\hline \multicolumn{9}{|l|}{ Total gain } \\
\hline LBW, kg & 179.5 & 210.4 & 206.5 & 209.2 & 13.16 & 0.28 & 0.40 & 0.35 \\
\hline EBW, kg & 150.6 & 174.2 & 164.8 & 171.5 & 8.27 & 0.14 & 0.54 & 0.37 \\
\hline Ash, kg & 7.2 & 8.8 & 8.5 & 9.9 & 0.53 & 0.04 & 0.09 & 0.84 \\
\hline Protein, kg & 28.6 & 33.8 & 32.0 & 34.7 & 2.56 & 0.28 & 0.52 & 0.70 \\
\hline Fat, kg & 27.3 & 30.4 & 28.6 & 24.5 & 2.72 & 0.87 & 0.45 & 0.25 \\
\hline Energy, Mcal & 395.7 & 462.8 & 438.1 & 410.1 & 36.51 & 0.87 & 0.45 & 0.25 \\
\hline \multicolumn{9}{|c|}{ Average daily gain } \\
\hline LBW, g/d & 820 & 961 & 908 & 922 & 60.0 & 0.27 & 0.71 & 0.36 \\
\hline EBW, g/d & 688 & 796 & 725 & 756 & 37.6 & 0.13 & 0.97 & 0.37 \\
\hline Ash, g/d & 33 & 40 & 37 & 44 & 2.4 & 0.05 & 0.08 & 0.83 \\
\hline Protein, g/d & 131 & 154 & 141 & 152 & 11.6 & 0.28 & 0.77 & 0.69 \\
\hline Fat, g/d & 125 & 139 & 126 & 108 & 12.2 & 0.89 & 0.30 & 0.26 \\
\hline Energy, Mcal/d & 1.80 & 2.11 & 1.93 & 1.81 & 0.134 & 0.54 & 0.54 & 0.19 \\
\hline
\end{tabular}

\section{Age Effects on Body Composition}

The effects of age across treatments with respect to changes in body chemical composition are shown in Figure 1. These changes can be generally characterized by an inverse relationship between age and empty body water, protein and ash content, and a positive relationship between age and empty body fat. Across treatments, empty body water and protein percentage decreased from 69.8 and $20.5 \%$ at 3 mo to $62.2(P<0.001)$ and $19.5 \%(P<0.04)$ at $10 \mathrm{mo}$, respectively. Conversely,

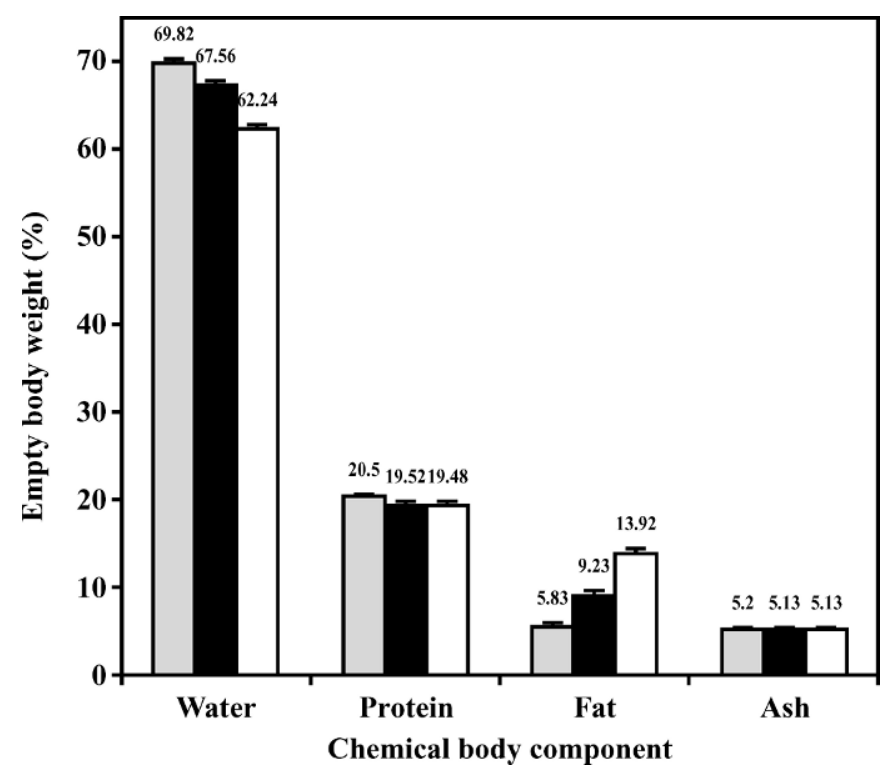

Figure 1. Changes in chemical body component distribution of Holstein growing heifers with age: 3 mo of age (gray bars), 5 mo of age (solid bars), and 10 mo of age (open bars). fat percentage of EBW, increased from 5.8 to $13.9 \%(P$ $<0.001)$ during the same time period.

\section{DISCUSSION}

Previous studies document increased $\mathrm{N}$ retention in response to a combination of bST injection and abomasal casein infusion in growing steers (Houseknecht et al., 1992; Bruckental et al., 1996). In the present study, bST administration altered metabolism of growing heifers in a manner that led to numerically greater protein and greater ash deposition without increasing fat deposition. Similar results were reported by Early et al. (1990a) for steers and by Radcliff et al. (1997) for Holstein heifers. A similar pattern was observed with added dietary RUP, as there was a tendency for increased protein and ash deposition without increased fat deposition (Early et al., 1990a). There was a tendency for bST administration to increase carcass weight in the present study is in agreement with previous reports (Early et al., 1990a; Radcliff et al., 1997). The present results indicate that numerically higher increments in carcass weight were the result of increased ash and protein deposition. Thus, the higher growth rates observed in the companion growth study (Moallem at al., 2004) resulted from increased accretion of skeletal tissue rather than increased adipose tissue.

In the present study, there was a tendency for both bST administration and RUP to alter organ weights, but in different ways. While administration of bST influenced the relative mass of many organs and tissues, the effects of added RUP seemed to be to increase mass of the digestive tract components, primarily the foregut, including rumen and reticulum. Previous studies with bST have investigated effects in lactating cows, which 

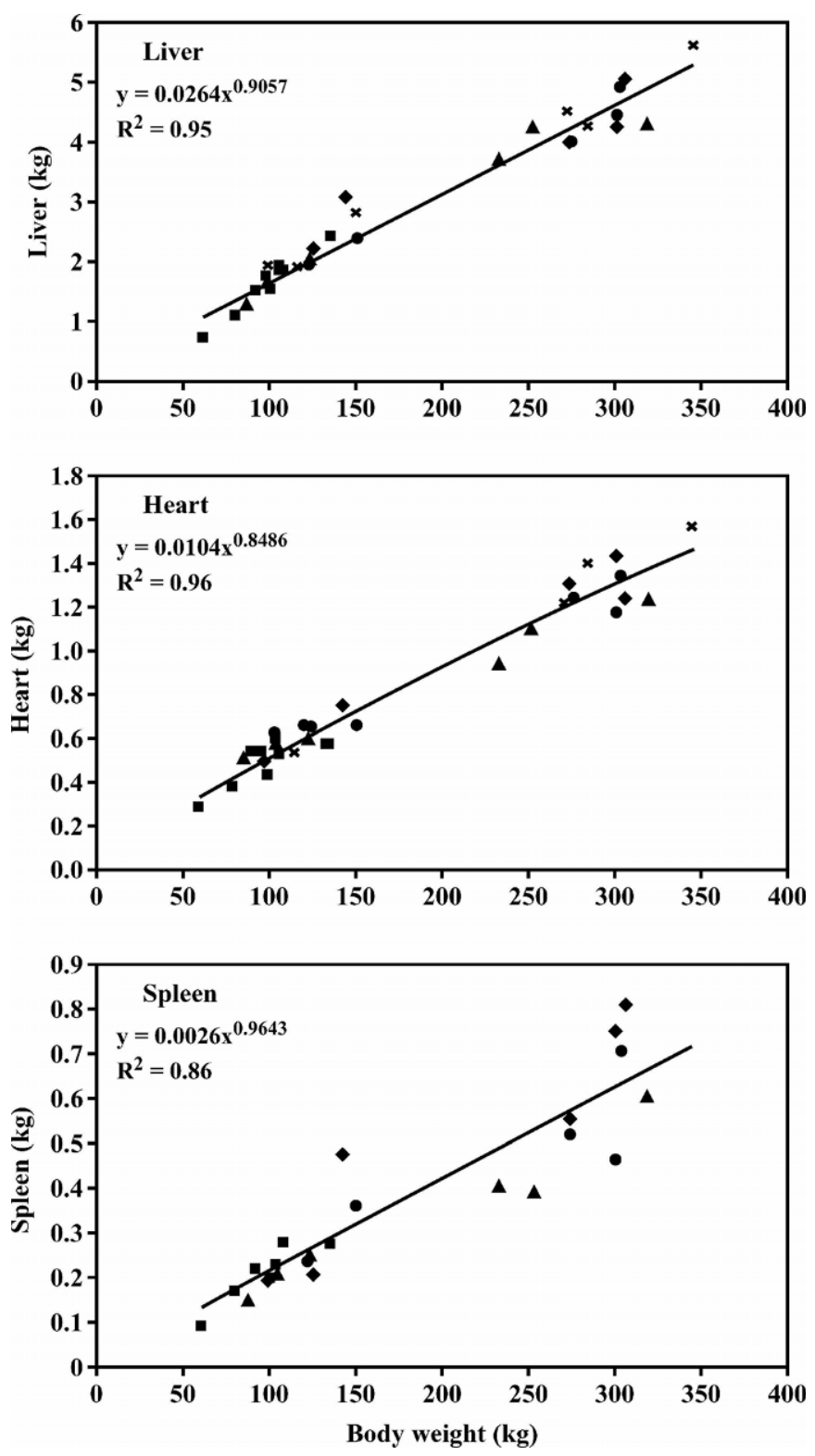

Figure 2. Weights of liver, heart, and spleen of heifers slaughtered at $3 \mathrm{mo}$ of age (pretreatment) (ם), or 5 and $10 \mathrm{mo}$ of age and fed the control diet (A), injected with bST (x), fed a diet with $2 \%$ added RUP $(+)$, or injected with bST and fed added RUP (bSTRUP) $(\diamond)$. The line represents the predicted weights of organs as a function of LBW expressed in allometric equations of the form: $\mathrm{Y}=\mathrm{A}(\mathrm{X})^{\mathrm{b}}$ where: $\mathrm{Y}$ is the organ mass $(\mathrm{kg}), \mathrm{A}$ is the fraction of body mass for the organ of interest, $\mathrm{X}$ is body mass and $\mathrm{b}$ is the scalar representing the change in organ size relative to body mass as the animal matures.

involve the intensive metabolism related to milk synthesis in the mammary gland. Somatotropin is a homeorhetic controller (Bauman, 1992) that influences a variety of tissues and organs via direct effect and indirect effects mediated through secondary factors like IGF-I and other somatomedins (Peel et al., 1987). Ef-
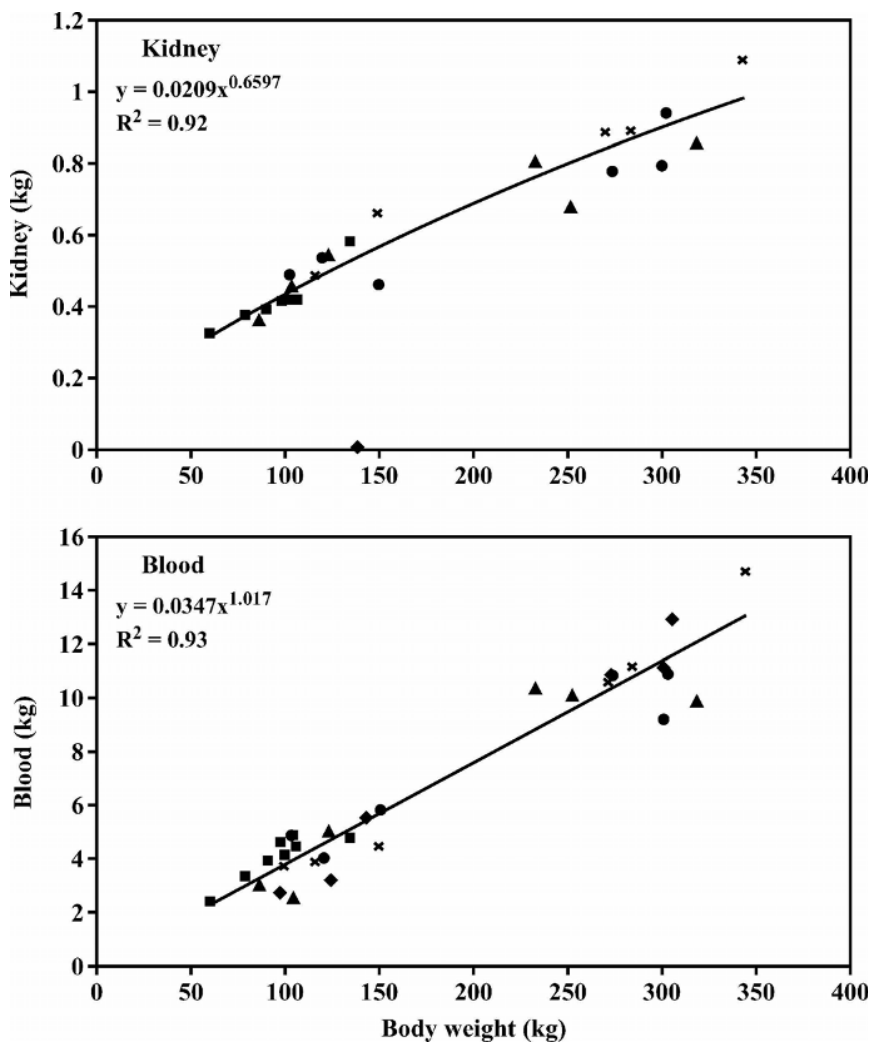

Figure 3. Weights of kidney and blood of heifers slaughtered at 3 mo of age (pretreatment) ( $\mathbf{\square})$, or 5 and 10 mo of age and fed the control diet ( $\boldsymbol{\Delta})$, injected with bST (x), fed a diet with $2 \%$ added RUP $(+)$, or injected with bST and fed added RUP (bSTRUP) $(\diamond)$. The line represents the predicted weights of organs as a function of LBW expressed in allometric equations of the form: $\mathrm{Y}=\mathrm{A}(\mathrm{X})^{\mathrm{b}}$ where: $\mathrm{Y}$ is the organ mass $(\mathrm{kg}), \mathrm{A}$ is fraction of body mass for the organ of interest, $\mathrm{X}$ is body mass and $\mathrm{b}$ is the scalar representing the change in organ size relative to body mass as the animal matures.

fects of somatotropin include coordination of organ and tissue metabolism to promote lactation. Under normal circumstances, relative organ mass is an indicator of changes in metabolism (McLeod and Baldwin, 2000).

Changes in relative organ mass induced by bST were observed in the current experiment and in previous studies (Sandles and Peel, 1987; Early et al., 1990a), may be a result of the adaptation to increased rate of metabolism. Davis et al. (1988) reported that bST injection in lactating cows increased cardiac output by $10 \%$ and mammary blood flow by $35 \%$. Moreover, Hart (1983) demonstrated that bST administration directly increased blood flow. The current finding that bST increased relative heart and blood mass at 10 mo of age, supports these findings and the concept that bST has direct effects on blood flow, as suggested by Peel et al. (1987).

Added RUP increased intake and tended to increase mass of the rumen-reticulum complex, whereas bST 

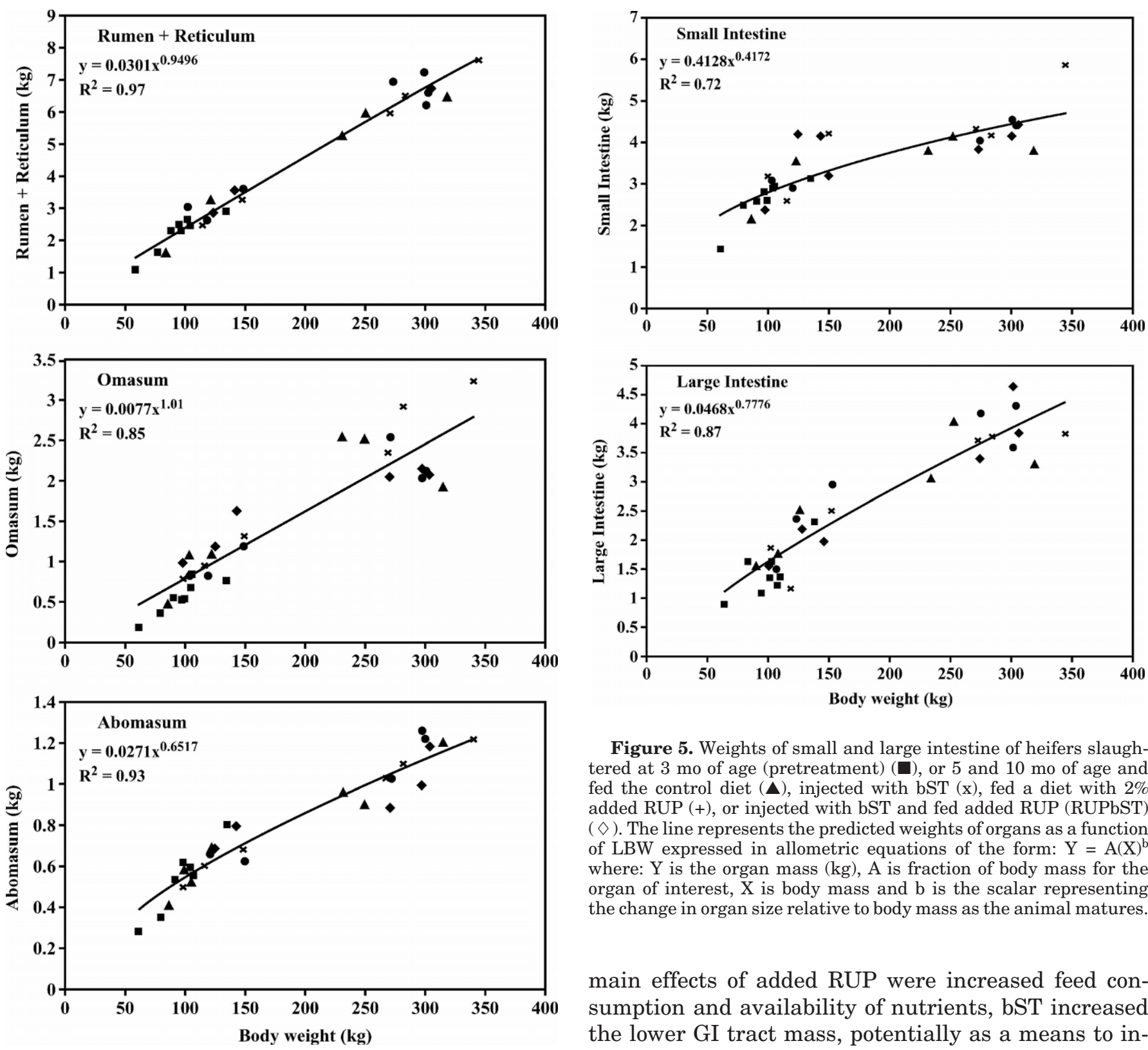

Figure 5. Weights of small and large intestine of heifers slaughtered at 3 mo of age (pretreatment) (ם), or 5 and 10 mo of age and fed the control diet (A), injected with bST (x), fed a diet with $2 \%$ added RUP (+), or injected with bST and fed added RUP (RUPbST) $(\diamond)$. The line represents the predicted weights of organs as a function of LBW expressed in allometric equations of the form: $\mathrm{Y}=\mathrm{A}(\mathrm{X})^{\mathrm{b}}$ where: $\mathrm{Y}$ is the organ mass $(\mathrm{kg}), \mathrm{A}$ is fraction of body mass for the organ of interest, $\mathrm{X}$ is body mass and $\mathrm{b}$ is the scalar representing the change in organ size relative to body mass as the animal matures.

main effects of added RUP were increased feed consumption and availability of nutrients, bST increased the lower GI tract mass, potentially as a means to increase nutrient absorption rate to support lean growth.

Figure 4. Weights of reticulorumen, omasum, and abomasum of heifers slaughtered at 3 mo of age (pretreatment) (ם), or 5 and 10 mo of age and fed the control diet ( $\boldsymbol{\Delta})$, injected with bST (x), fed a diet with $2 \%$ added RUP (+), or injected with bST and fed added RUP (bSTRUP) $(\diamond)$. The line represents the predicted weights of organs as a function of LBW expressed in allometric equations of the form: $\mathrm{Y}=\mathrm{A}(\mathrm{X})^{\mathrm{b}}$ where: $\mathrm{Y}$ is the organ mass $(\mathrm{kg}), \mathrm{A}$ is fraction of body mass for the organ of interest, $\mathrm{X}$ is body mass and $\mathrm{b}$ is the scalar representing the change in organ size relative to body mass as the animal matures.

tended to increase weights of the lower digestive tract including the large and small intestine. The different effects of RUP and bST on digestive tract components possibly suggest different modes of action. Whereas the The increased intestinal mass is consistent with somatotropic coordination of increased absorption and availability of nutrients as reported by Bauman (1992) for minerals in nonlactating cows. Increased organ and tissue growth induced by bST in the current study reflect changes in metabolites required to support increased skeletal growth of growing animals. This is similar to the increased metabolic supply to the mammary gland for lactating cows in response to bST (Peel and Bauman, 1987; Chalupa and Galligan, 1989).

There are few previous reports of individual digestive tract components and visceral organ weights taken over time during prepubertal growth of dairy heifers. The relationship between organ weights and BW for heifers 


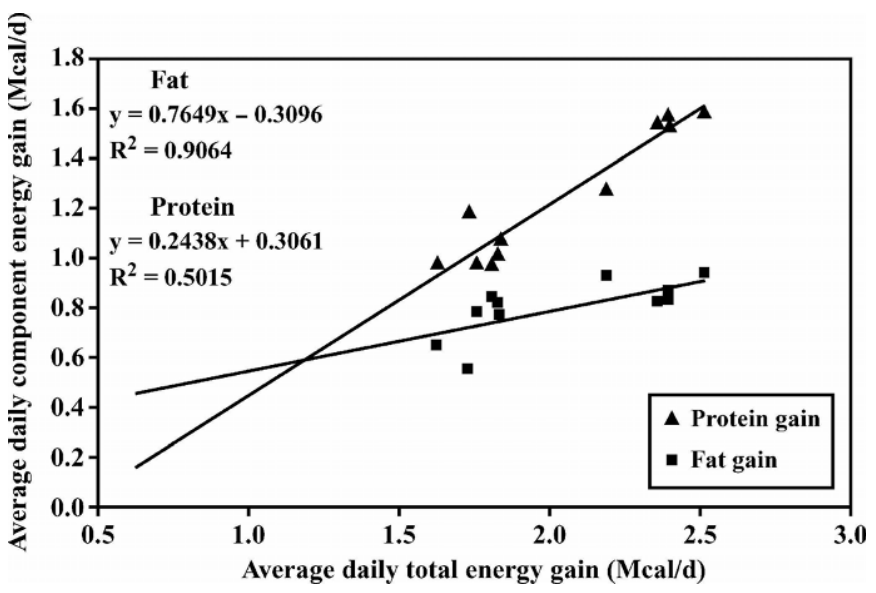

Figure 6. Partition of energy deposition between protein ( $\square$ ) and fat $(\boldsymbol{\Lambda})$ energy gain in different total energy gain rates between 3 and 10 mo of age of growing Holstein heifers.

slaughtered at 3 (pretreatment), 5 , and 10 mo of age (treatment groups) are shown in Figures 2 to 5 . As suggested by Baldwin (1995), data were fitted to standard allometric equations of the form: $\mathrm{Y}=\mathrm{A}(\mathrm{X})^{\mathrm{b}}$ where: $\mathrm{Y}$ is the organ mass in kilograms, $\mathrm{A}$ is the fraction of body mass for the organ of interest, $\mathrm{X}$ is body mass, and $b$ is a scalar representing the change in organ size relative to body mass as the animal matures. Figures 2 to 5 identify individual observations by treatment groups and suggest that the relationship between BW and organ weights were randomly distributed across treatments.

The scalars in the allometric equations relating mass of liver, heart, spleen, and blood were 0.91, 0.85, 0.96, and 1.02, respectively, and are not different from 1 ( $P$ $>0.1$ ). Thus, linear equations can be used to describe the relationship between these organs and BW. Relative to BW, kidney mass increased at a decreasing rate over time, thus the scalar for kidney mass (0.66) differed from 1. For rumen-reticulum and omasum growth, scalars were also not different from $1(P>0.1)$, suggesting a nearly linear relationship with $\mathrm{BW}$. In contrast, abomasum and small and large intestines increased at a decreasing rate, much the same as for kidney.

Growth rates of visceral organs generally coincide with functional development. Postweaning rumen development is associated with increases in the relative volume and mass of rumen-reticulum complex. There are many factors regulating organ and tissue growth processes, including genetic, nutritional, and environmental factors. Under normal circumstances, the developmental stage of each functional organ determines the relative growth rate, as was demonstrated by McLeod and Baldwin (2000). Organ metabolic activity can be stimulated or depressed by external factors such as environmental and nutritional circumstances, or internal factors such as metabolic status and interrelated organs. The linear growth of the rumen-reticulum and omasum mass in relation to body mass between 3 and 10 mo of age (Figure 4) in the current study corresponds with a linear increase in DMI until 10 mo of age (data not shown). In contrast, the relationship between other digestive tract components and live weight increased at a decreasing rate relative to BW (Figures 4 and 5). These differences may simply be a function of accelerated rates of development of the posterior digestive tract development during the postweaning period in order to match digestion and absorption of metabolites. Because the rumen, reticulum, and omasum are the initial digestive tract compartment, their mass and especially volume are influenced directly by the volume of feed intake and mass, whereas the other digesta tract compartments (abomasum and small and large intestine) are influenced by metabolic needs rather than increased feed volume associated with increased DMI.

\section{Rates and Partition of Energy Deposition}

To illustrate the relationship between rates of energy gain and the partition of gain between fat and protein energy, fat energy and protein energy gain were regressed against total energy gain of heifers slaughtered at $10 \mathrm{mo}$ of age (Figure 6). In this instance, energy deposited as fat was calculated as $9.4 \mathrm{Mcal} / \mathrm{kg}$ of fat (NRC 2001), and protein energy was calculated as the difference between total and fat energy deposition. As the total energy gain was increased, the proportion as fat energy was 0.76 and for protein energy was 0.24 . As age increased, the proportion of empty body fat increased while water, protein, and ash content decreased (Figure 1), consistent with previous reports (Waldo et al., 1990; Fox et al., 1999; NRC, 2001). However, most of the age effects relate to changes in absolute rates of energy deposition as is shown in Figure 6.

The partition of energy deposition as fat (0.76) and protein (0.24) appeared to be constant (Figure 6) with increasing rate of overall energy deposition. These are consistent with published requirements (NRC, 2001), where net energy per unit BW gain increases with increasing rate of BW gain. Equations for proportional fat and protein deposition are identical to those reported by Waldo et al. (1990) for Holstein steers but differ from their finding for growing heifers (Waldo et al., 1997). As was suggested by Waldo et al. (1990), the discrepancy between studies may be due to differences in experimental design. The Waldo et al. (1997) heifer study was based on slaughter at a fixed animal weight and variable time, whereas the present experiment and pre- 
vious study in steers (Waldo et al., 1990) were based on slaughter at variable weights and a fixed time. Despite the discrepancy in equations, the intersection of the 2 lines, i.e., the point at which rates of protein and fat deposition would be equal occurred at a total energy gain of $1.19 \mathrm{Mcal} / \mathrm{d}$ in the present study, nearly identical to the value of 1.18 reported by Waldo et al. (1990). Rates of energy deposition (Table 8) for the control, bST, RUP, and bSTRUP treatments from 3 to $10 \mathrm{mo}$ were $1.77,2.06,1.99$, and $1.85 \mathrm{Mcal} / \mathrm{d}$ as compared with NRC (2001) predicted rates of 1.60, 2.03, 2.00, and 2.03 $\mathrm{Mcal} / \mathrm{d}$, respectively. Predicted energy deposition was slightly lower than measured values for control heifers and higher for bSTRUP heifers. Because increased growth rates occurred in the bSTRUP treatment without increased rates of fat deposition (Table 8), NRC (2001) estimates of energy deposition were higher than measured rates. In other treatments, there was close agreement between predicted and measured values, suggesting that energy requirement for growth suggested by NRC (2001) can be used with confidence.

\section{CONCLUSIONS}

Changes in measured rates of protein, ash, and fat deposition suggested that bST, and to a smaller extent RUP, could be used to increase growth rates in dairy heifers without enhancing adiposity. Increased deposition of body protein and ash suggest that rates of skeletal growth can be enhanced without the detrimental effects of fattening usually associated with accelerated growth. Changes in relative visceral organ masses in response to bST administration were consistent with adaptations needed to support increased rates of empty body protein and ash deposition. In contrast to previous experiments in which energy intake was used to increase growth, and as a consequence fat deposition, heifers treated with bST and RUP in the present experiment achieved increased growth rates without increased energy deposition. This demonstrates that hormonal and nutritional manipulations can increase skeletal growth rates of prepubertal heifers without concomitant increases in fat deposition.

\section{ACKNOWLEDGMENTS}

The authors gratefully acknowledge the kind donation of the milk replacer used in the preweaning phase of the experiment by Land O' Lakes, Inc. (St. Paul, MN). We also wish to thank Tom Moreland, Tommy Junis, Daniela Bals, and Rachael Dayton at the Central Maryland Research and Education Center Dairy Unit for their assistance with animal care and data collection during the project.

\section{REFERENCES}

American Society for Testing and Materials. 1978. ASTM standard for Bomb calorimetry and Combustion Methods. Designation: D 2015-2078 (1978). Standard method for gross calorific value of solid fuel by the adiabatic calorimeter. Authorized Reprint. Parr Instruments Co, Moline, IL.

Baldwin, R. L., V. 1995. Modeling Ruminant Digestion and Metabolism. Chapman and Hall, London, UK.

Barash, H., Y. Bar-Meir, and I. Bruckental. 1994a. Effects of a lowenergy diet followed by a compensatory diet on growth, puberty and milk production in dairy heifers. Livest. Prod. Sci. 39:263268.

Barash, H., I. Peri, A. Gertler, and I. Bruckental. 1994b. Effects of energy allowance and cimaterol feeding during the heifer rearing period on growth, puberty and milk production. Anim. Prod. 59:359-366.

Bauman, D. E. 1992. Bovine somatotropin: Review of an emerging animal technology. J. Dairy Sci. 75:3432-3451.

Bruckental, I., G. Huntington, C. Kirk-Baer, and R. Erdman. 1997. The effect of abomasal infusion of casein and recombinant somatotropin hormone injection on nitrogen balance and amino acid fluxes in portal-drained viscera, net hepatic and total splanchnic blood in Holstein steers. J. Anim. Sci. 75:1119-1129.

Capuco, A. V., J. J. Smith, D. R. Waldo, and C. E. Rexroad, Jr. 1995. Influence of prepubertal dietary regimen on mammary growth of Holstein heifers. J. Dairy Sci. 78:2709-2725.

Chalupa, W., and D. T. Galligan. 1989. Nutritional implications of somatotropin for lactating cows. J. Dairy Sci. 72:2510-2524.

Clark, R. D., and R. W. Touchberry. 1962. Effect of body weight and age at calving on milk production in Holstein cattle. J. Dairy Sci. 45:1500-1510.

Davis, S. R., R. J. Collier, J. P. McNamara, and H. H. Head. 1988. Effect of growth hormone and thyroxine treatment of dairy cows on milk production, cardiac output and mammary blood flow. J. Anim Sci. 66:70-79.

Early, R. J., B. W. McBride, and R. O. Ball. 1990a. Growth and metabolism in somatotropin-treated steers: Carcass and noncarcass tissue components and chemical composition. J Anim. Sci. 68:4144-4152.

Fox, D. G., M. E. Van Amburgh, and T. P. Tylutki. 1999. Predicting requirements for growth, maturity, and body reserves in dairy cattle. J. Dairy Sci. 82:1968-1977.

Grings, E. E., D. M. deAvila, R. G. Eggert, and J. J. Reeves. 1990. Conception rate, growth, and lactation of dairy heifers treated with recombinant somatotropin. J. Dairy Sci. 73:73-77.

Hardville, D. A., and C. R. Henderson. 1966. Interrelationships among age, body weight, and production traits during first lactation of dairy cattle. J. Dairy Sci. 49:1254-1261.

Hart, I. C. 1983. Endocrine control of nutrient partition in lactating ruminants. Proc. Nutr. Soc. 42:181-186.

Heinrichs, A. J. 1993. Raising dairy replacements to meet the needs of the 21st century. J. Dairy Sci. 76:3179-3187.

Heinrichs, A. J., and G. L. Hargrove. 1987. Standards of weight and height for Holstein heifers. J. Dairy Sci. 70:653-660.

Hoffman, P. C. 1997. Optimum body size of Holstein replacement heifers. J. Anim. Sci. 75:836-845.

Houseknecht, K. L., D. E. Bauman, D. G. Fox, and D. F. Smith. 1992. Abomasal infusion of casein enhances nitrogen retention in somatotropin-treated steers. J. Nutr. 122:1717-1725.

Kewon, J. F., and R. W. Everett. 1986. Effect of days carried calf, days dry, and weight of first calf heifers on yield. J. Dairy Sci. 69:1891-1896.

Markusfeld, O., and E. Ezra. 1993. Body measurements, metritis, and postpartum performance of first lactation dairy cows. J. Dairy Sci. 76:3771-3777.

McLeod, K. R., and R. L. Baldwin. 2000. Effects of diet forage: Concentrate ratio and metabolizable energy intake on visceral organ growth and in vitro oxidative of gut tissues in sheep. J. Anim. Sci. 78:760-770.

Moallem, U., G. E. Dahl, E. K. Duffey, A. V. Capuco, and R. A. Erdman. 2003. Bovine somatotropin and rumen-undegradable 
protein effects on skeletal growth in prepubertal dairy heifers. J. Dairy Sci. 87:3881-3888.

National Research Council. 2001. Nutrient Requirement of Dairy Cattle. 7th rev. ed. Natl. Acad. Sci., Washington, DC.

Peel, G. J., and D. E. Bauman. 1987. Somatotropin and lactation. J. Dairy Sci. 70:474-486.

Radcliff, R. P., M. J. Vandehaar, A. L. Skidmore, L. T. Chapin, B. R. Radke, J. W. Lloyd, E. P. Stanisiewski, and H. A. Tucker. 1997. Effects of diet and bovine somatotropin on heifer growth and mammary development. J. Dairy Sci. 80:1996-2003.

Sandles, L. D., and C. J. Peel. 1987. Mammogenesis and first lactation milk yield of identical-twin heifers following pre-pubertal administration of bovine growth hormone. Anim. Prod. 45:349-357.

SAS User's Guide: Statistics, Version 8.0 Edition. 2000. SAS Inst. Inc., Cary, NC.

Sejrsen, K. 1994. Relationships between nutrition, puberty and mammary gland development in cattle. Proc. Nutr. Soc. 53:103-111.
Sejrsen, K., J. T. Huber, and H. A. Tucker, and R. M. Akers. 1982. Influence of nutrition on mammary development in pre-and postpubertal heifers. J. Dairy Sci. 65:793-800.

Sieber, M., A. E. Freeman, and D. H. Kelley. 1988. Relationships between body measurements, body weight, and productivity in Holstein dairy cows. J. Dairy Sci. 71:3437-3445.

Tucker, H. A. 1987. Quantitative estimates of mammary growth during various physiological states: A review. J. Dairy Sci. 70:1958-1966.

Waldo, D. R., H. F. Tyrrell, A. V. Capuco, and C. E. Rexroad. 1997. Components of growth in Holstein heifers fed either alfalfa or corn silage diets to produce two daily gains. J. Dairy Sci. 80:1674-1684.

Waldo, D. R., G. A. Varga, G. B. Huntington, B. P. Glenn, and H. F. Tyrrell. 1990. Energy components of growth in Holstein steers fed formaldehyde and formic acid treated alfalfa or orchardgrass silage at equalized intake of dry matter J. Anim Sci. 68:37923804 . 